\title{
Н.А. Жерлицына
}

\section{«ЗАЩИТНИК УГНЕТЕННОГО МАРОККО»: ОСВЕЩЕНИЕ РИФСКОЙ ВОЙНЫ В СОВЕТСКОМ СОЮЗЕ В 1920-х гГ.}

\begin{abstract}
Исследуются особенности освещения Рифской войны в Советском Союзе. Движение сопротивления двенадцати племен горного района Риф в Марокко французскому и испанскому колониализму привлекало особое внимание как руководства СССР, так и советской прессы по политическим и идеологическим причинам. Анализ советской позиции по безусловной поддержке освободительной борьбы марокканцев показывает наличие противоречий и идеологических натяжек. Основой для данного исследования стали работы руководителей страны того периода, документы Коминтерна и публикации востоковедной и идеологической прессы СССР 1920-х гг.

Ключевые слова: СССР; Марокко; Рифская война; антиколониальная борьба; идеологическая печать.
\end{abstract}

Рифская война 1921-1926 гг., одна из самых кровавых и жестоких в период между двумя мировыми войнами, представлялась событием мирового масштаба изза калибра сил, вовлеченных в противостояние, и вероятных разрушительных последствий для западной колониальной системы. Движение сопротивления берберских племен Северного Марокко под руководством Мухаммада ибн Абд-аль-Карима аль-Хаттаби испанскому и французскому колониальному присутствию привело к созданию в 1921 г. военно-территориального союза двенадцати рифских племен, получившего название Рифской республики. В течение пяти лет самопровозглашенная берберская республика вела победоносную войну против Испании, под протекторатом которой находился горный район Риф. Вмешательство Франции, которая не только мобилизовала против маленького народа 200-тысячную армию, оснащенную современным вооружением, но и сумела благодаря оккупации бассейна р. Уэрги - житницы Рифа - подвергнуть восставших угрозе голодной блокады, было решающим фактором, определившим ряд поражений рифских войск и, в конечном счете, капитуляцию Абдаль-Карима в 1926 г.

За событиями в далеком Марокко внимательно следили в молодом советском государстве. Большевистское руководство СССР, нацеленное в своей политике в 1920-е гг. на идею мировой пролетарской революции, связывало ее с ростом революционного движения на Востоке. Союз большевиков с «угнетенными народами Востока», которые бы вместе противостояли мировой империалистической системе, представлялся возможным и даже необходимым. Пробуждение народов Азии и Африки к активной политической жизни и национально-освободительная борьба, развернувшаяся в колониальных странах, подтверждали, казалось, теории коммунистических идеологов и ставили перед Советским государством новые политические задачи. Первое послеоктябрьское десятилетие стало временем появления в СССР новой востоковедческой литературы и публицистики. Востоковедение приобрело необычайную актуальность. Изменилась его методологическая база - ею стал так называемый марксизм-ленинизм, и практические задачи - власть требовала от ученых уделять главное внимание вопросам национальноосвободительного движения народов Востока.

На протяжении всех 1920-х гг. публикации, посвященные марокканской тематике, занимали на страницах новых востоковедных, военных и идеологических журналов, таких как «Новый Восток», «Восток и колонии», «Борьба классов», «Военный вестник», «Военная мысль и революция», «Большевик» и «Красная новь», видное место. Скрупулезное внимание со стороны советских специалистов ко всем деталям разворачивавшегося в Северной Африке конфликта было связано с серьезными международными осложнениями и, не в последнюю очередь, надеждами, которые возлагали в Москве на разрастание революционного движения на арабском Востоке: «Марокко может стать исходным пунктом, базой повстанческо-революционного движения, которое из Марокко перекинется в Алжир, из Алжира в Тунис, из последнего в Триполи, чтобы слиться с сильным революционным движением в Египте» [1. С. 46]. Свидетельством особого внимания к ситуации в Марокко со стороны властей СССР стала публикация в 1925 г. книги «Европейские цивилизаторы и Марокко», автором которой был М. Мирский (псевдоним видного советского государственного деятеля, одного из крупных военачальников Красной Армии М.В. Фрунзе) [2]. Эта работа во многом задала идеологические и научные стандарты, в соответствии с которыми отечественные ученые и журналисты подходили к трактовке событий в Северной Африке.

Безусловно, поддерживая борьбу рифского народа за освобождение от колониальной зависимости, советские авторы, руководствуясь идеологическими догмами, исходили из постулата об «антиимпериалистическом» и «национально-освободительном» характере войны в Рифе. «Героическая борьба маленького народа рифов против целых полчищ французского и испанского империализма составляет одну из наиболее ярких страниц революционно-освободительной борьбы в колониях» [3. С. 2]. «Борьба рифов внесла ценный вклад 
в искусство вооруженного восстания колониальных народов в эпоху империализма и пролетарских революций и еще раз подтвердила основные марксистсколенинские принципы вооруженного восстания», - писал автор «Военно-исторического журнала» [4. С. 147]. Однако такая оценка сформировалась далеко не сразу и имела много слабых мест. Прежде всего потому, что речь шла о стране, находившейся на более ранней фазе исторического развития, не предусматривающей наличия условий, которые, согласно учению марксизмаленинизма, считались необходимыми для зарождения революционного движения. Феодально-патриархальное Марокко не обладало ни мало-мальски развитой промышленной экономикой, ни наличием национальной буржуазии и пролетариата; сопротивление колонизаторам оказывали кочевники и крестьяне, а возглавляла это движение родоплеменная знать в лице местного аристократа - вождя племени бени-уриагель Абд-альКарима.

Особенно бурные дискуссии развернулись среди членов Французской Коммунистической партии, которая возглавила антивоенное движение в Европе. Французские коммунисты спорили, следует ли поддерживать Абд-аль-Карима, ведь он «представляет совершенно иные социальные слои и преследует совершенно иные цели» [5. С. 74]. Члены «правого крыла» Компартии, Социалистическая партия Франции выступали против пораженческих лозунгов и эвакуации Марокко, называя войну, которую ведёт марокканский народ, реакционной, а Абд-аль-Керима - «вождём-феодалом, а не революционером», которому можно оказывать лишь условную, ограниченную поддержку «в той мере, в какой он проявляет подлинную революционность» [6. C. 76]. В ответ на это генеральный секретарь ФКП П. Семар парировал: «Мы поддерживаем не лично Абд-аль-Керима, а лишь в его лице вождя, стоящего во главе национального движения, направленного против французского империализма. Когда этот период борьбы с французским империализмом будет окончен, мы будем бороться с этим вождем-феодалом. Но это будет лишь тогда, когда он не будет более бороться с нашими империалистами, в том случае, если его власть тяжело ляжет на рифских крестьян» [7. С. 137].

Чтобы пресечь ослабляющие коммунистическое движение разногласия, его руководству - Коминтерну - пришлось принять специальную резолюцию на VI пленуме Исполнительного комитета Коминтерна. Она дала ответ на вопрос о характере войны в Рифе: «Без сомнения мы должны бороться с социальными и религиозными предрассудками, с панисламизмом колониальных народов и содействовать развитию у них массового рабоче-крестьянского движения. Но когда воинственные племена восстают против империализма метрополий и воюют за свою независимость, мы должны вести борьбу не против их вождей, хотя им и свойственны некоторые предрассудки, а против империализма» [5. С. 74]. Коминтерн и Крестинтерн опуб- ликовали воззвание «К рабочим Франции, Испании и Италии», в котором характер рифской войны был четко определен: «Это - империалистическая война; она направлена против угнетенного народа» [8. С. 82]. Позиция Коминтерна, несомненно, отражала взгляды высшего партийного руководства Советского Союза: Генеральный секретарь ЦК ВКП(б) И.В. Сталин неоднократно в речах и статьях называл войну в Рифе «национальным восстанием против империализма» и указывал, что задачей коммунистов является содействие «созданию единого национального фронта против империализма» даже в такой стране, как Марокко, которое «совершенно неразвито в промышленном отношении и не имеет своего рабочего класса» $[9$. C. 145].

Противоречивая картина складывалась на страницах советских журналов и когда речь заходила о деятельности французской Компартии по противодействию военной кампании в Марокко. В Москве горячо поддерживали как выдвинутые французскими товарищами лозунги - незамедлительную эвакуацию Марокко, немедленный мир, признание независимости республики рифов, так и тактику их действий - работу в парламенте, на страницах партийной печати, среди рабочих и солдат, организацию «комитета действия» и забастовок. Факт начала репрессий французских властей против членов Компартии за антивоенные выступления и запрет на распространение рупора Компартии газеты «Юманите» в Марокко также расценивались в советской прессе как свидетельство действенности шагов, предпринятых французскими коммунистами. «Коммунистическая пропаганда оказала свое влияние в том отношении, что, разоблачив истинный характер войны с рифами, она убила всякий энтузиазм в солдатской массе. Солдаты сражались с рифами изпод палки под угрозой расстрела и нередки были случаи, когда французские отряды бежали перед горстью рифских партизан», - такова была типичная оценка на страницах советского журнала [10. С. 10].

Однако ниже тот же автор М.П. Павлович, между прочим первый ректор Московского института востоковедения и создатель журнала «Новый Восток», вынужден признать, что антивоенные настроения не получили во Франции широкого распространения: «Народные массы Франции еще не доросли до идеи добровольного отказа от колоний. <..> Миллионы французских крестьян и рабочих уверены в том, будто их жизненные интересы самым тесным образом связаны с сохранением могущества Франции как колониальной империи» [Там же. С. 12]. Неудачу Компартии Франции по организации общенационального антивоенного фронта разбирали на пленуме Исполкома Коминтерна весной 1926 г. Основной ошибкой партии была названа недостаточная борьба с «правой опасностью».

Советский Союз настойчиво и последовательно отстаивал интересы народа Рифа в вопросе определения 
сути происходившего в Марокко конфликта. Французская, а вместе с ней и вся другая западная пресса называла происходящее «полицейской экспедицией» против «повстанцев», усмирением «банд дикарей». «Официальные сообщения французского правительства рисуют дело как “противодействие набегу банд рифиотов”. Мы настаиваем на слове война, и вдобавок, такая, где применяются все современные технические средства борьбы», - заявлял советский «Военный вестник» [11. С. 33]. С точки зрения советского государства, всякая война между народом-поработителем и народомугнетаемым (в частности, в колониях) являлась, безусловно, войной в международно-правовом смысле, и рифы самим фактом восстания получали право на международное признание.

Еще одним важным идеологическим моментом, обеспечивавшим поддержку народа Рифа со стороны Советского Союза, было то, что марокканское движение сопротивления французским и испанским колонизаторам не носило явного религиозного характера. Несомненно, ислам играл важную роль в сплочении восставших, но не религия определяла политику Рифской республики. «Движение Абд-аль-Карима так же далеко стояло от “борьбы за торжество ислама”, как французские карательные экспедиции от “борьбы за цивилизацию"», - отметил Д. Лебедев, чей труд «Республика Риф» был написан на основе мемуаров вождя рифского народа [3. С. 5]. Абд-аль-Карим настойчиво подчеркивает в своих мемуарах, что целью борьбы были освобождение от колонизаторов и независимость республики [Там же. С. 16]. Примечательно, что в оценке восстания в Рифе как движения национального советские специалисты были солидарны со своими французскими коллегами. Корреспондент французского официоза «Тан» Р. Канн писал: «Пропаганда Абдаль-Карима носит современный характер. Она не имеет целью вызвать антихристианское движение. <..> Их деятельность носит национальный характер, а не религиозный. На этой струне наигрывает властитель Рифа, чтобы изгнать сперва испанцев, а затем нас» [12].

Советские специалисты в военной области и международных отношениях вполне объективно оценивали неравные силы и шансы противников - «маленького геройского народца» и «полчищ французского и испанского империализма» [3. С. 2]. В период подготовки военной операции против мятежного Рифа в 1925 г. французы увеличили свою армию в Марокко с 80 до 220 тыс. человек, перевели в Марокко 1/5 своих авиационных сил, перебросили большое количество танков, горных орудий, пулеметов. Испанцы высадили 100тысячную армию. Таким образом, против небольшой армии Абд-аль-Карима - от 50 до 60 тыс. человек выступала «вооруженная до зубов» армия в 340360 тыс. войск [13. С. 31]. В советских публикациях отмечалось, что Франция - «самая сильная военносухопутная держава в мире» и поэтому война марокканских кабилов - «геройская, но безнадежная» [14.
C. 31]. «Французы не раз одерживали успехи в борьбе с рифиотами и в дальнейшем быть может окончательно задушат своих противников. Но победами эти успехи назвать нельзя: они - результат численного и технического превосходства, и лишены того, что дает истинную победу - качественного превосходства бойцов одной стороны над другой», - рассуждал военный специалист Ланговой в «Военном вестнике» [15. С. 50].

Для прессы молодой Советской республики, страны, жившей в условиях Гражданской войны и иностранной интервенции, особый интерес представляло изучение форм, средств и методов ведения военных действий как со стороны «культурных» армий Франции и Испании, так и со стороны «диких» повстанцев с их партизанской тактикой. Помимо превосходства в силе были и другие причины французской победы в Марокко: будучи опытными колонизаторами, французы умело устанавливали связи с местными элитами, давая им возможность обогащения. Они склоняли на свою сторону вождей племен путем предоставления привилегий, например земельных участков. Племена, оставшиеся верными французам и участвовавшие в боевых действиях против отрядов Абд-аль-Карима, обогатили свои селения на тысячи голов скота, не говоря о другой военной добыче. Некоторые советские авторы называли эту французскую политику «экономического стимулирования» подкупом.

По мнению советских международников, народ Рифа имел шанс на завоевание свободы только в случае разрастания антиколониальной борьбы на весь Магриб: «Единственная помощь рифам может прийти со стороны угнетенных колониальных народов и международного пролетариата» [12. С. 37]. Надежду на такое развитие событий давала и политика самого Абд-альКарима, взывавшего к солидарности арабов Магриба. В августе 1925 г., накануне высадки французских и испанских войск в Марокко, вождь рифского народа обратился с прокламацией к населению Алжира и Туниса: «Мусульмане Алжира и Туниса! Настал момент для всех мусульманских народов порвать цепи рабства, прогнать насильников и освободить свою территорию. Воспользуйтесь этим благоприятным обстоятельством и восстаньте вместе с нами, чтобы освободить всю нашу территорию! ... О, мои алжирские и тунисские братья, час нашего освобождения от ига Франции настал... Сплотимся вместе, и мы будем достаточно сильны, чтобы прогнать наших врагов. Таким образом, создается республика, в состав которой войдут все страны Северной Африки...» [10. С. 15].

Действительно, героическое сопротивление рифов под руководством Абд-аль-Карима дало сильный толчок росту национально-освободительного движения среди мусульманского населения Алжира и особенно Туниса, где партия «Дустур» выставила требования полной независимости страны и создания единого фронта со сражающимися Марокко и Сирией. Абд-альКарим угрожал стать национальным вождем всего 
освободительного движения в Северной Африке. Борьба рифов против европейских колонизаторов вызвала необычайное брожение во всех французских колониях Северной Африки. Как сообщал корреспондент «Тан» в корреспонденции из Туниса в мае 1925 г., тунисские националисты желают поражения французских войск. Власти метрополии знали об этих настроениях и стремились «покончить с восстанием в Испанском Марокко и потушить здесь костер, искры от которого могут зажечь пожар во всем мусульманском мире» [14]. Генеральный резидент Франции маршал Лиотэ даже запретил распространение во французском Марокко наряду с коммунистической «Юманите» газет «Зора» и «Нада» из Туниса, «Тред-юнион» из Алжира, «Эль-Абрам» и «Эль-Лива аль-Акбар» из Каира, «Вадинниль» из Александрии [12. С. 37]. Однако ни в Алжире, ни в Тунисе это движение поддержки рифов не привело к каким-либо активным выступлениям, которые могли бы повлиять на исход франко-рифской войны. В Тунисе, как и в Египте, в Триполи, в Алжире дело помощи движению Абд-аль-Карима выразилось лишь в распространении соответствующих прокламаций, в сборе пожертвований в пользу рифов. Надежды противников мирового империализма на энергичное вмешательство французского и испанского пролетариата в войну с рифами также оправдались лишь в небольшой степени. Имелись случаи перехода туземных солдат из французской армии на сторону Абд-аль-Карима, некоторые племена французского Марокко сражались под знаменем Рифской республики. Однако всеобщего восстания в Алжире, Марокко и Тунисе, восстания, которое бы могло привести к изгнанию французов из Северной Африки, не произошло. «Судьбу Рифа могло решить иначе только всеобщее восстание народов Северной Африки, но оно не было еще подготовлено ходом истории», - с сожалением заключил Д. Лебедев [3. С. 16].

В значительной степени интерес в СССР к событиям в Марокко был связан с международной напряженностью, возникшей вследствие восстания Рифа. Марокко, утратившее независимость гораздо позднее соседних Алжира и Туниса, только в 1912 г., долгие десятилетия было и в 1920-х гг. оставалось предметом вожделений мировых «империалистических хищников». Упорное соперничество Франции, Великобритании, Германии и Испании привело к компромиссному разделу Марокко, лишившему страну не только независимости, но и целостности: Франция получила наибольшую зону (до 80\% площади Марокко), Испании достались небольшие территории на крайнем юге и севере страны, а город Танжер был выделен в особую международную зону. Но этим соглашениям, как и ряду последующих, не удалось ликвидировать так называемый «марокканский вопрос». Марокко не перестало являться предметом споров и очагом конфликтов: «Марокко всегда было одним из больных мест мирового империализма. <..> События, вспыхивавшие в этом небольшом уголке северо-западной Африки, не раз уже гро- зили зажечь пламя мирового пожара», - отмечал М.В. Фрунзе [2. С. 7].

«Одна из международных болячек» - так была озаглавлена статья, посвященная Марокко, в газете «Известия» в 1925 г. [16]. Причину непрекращающегося противоборства ведущих европейских держав за Марокко советские авторы объясняют прежде всего его важным стратегическим положением. Географически страна господствовала над двумя великими путями путем в Средиземное море через Гибралтар и над другим путем, идущим вокруг Африки, мимо мыса Доброй Надежды в Индию. В геополитическом смысле Гибралтар считался в начале XX в. наиболее важным из всех европейских проливов: после строительства Суэцкого канала значение Гибралтара еще более возросло, так как он охранял не только доступ к Средиземному морю, но также к Индийскому и Тихому океанам. Борьба за Марокко и особенно его северную часть с Танжером была борьбой за преобладание в международном морском пространстве и выходила за рамки регионального противоборства, что могло привести к конфликтам международного масштаба. Советские авторы того времени так характеризовали ситуацию: «Мароккский вопрос сыграл большую и зловещую роль в истории мировой войны, являясь одним из узлов империалистических противоречий» [17. С. 111]. «В течение периода, предшествовавшего Первой мировой войне, Марокко играло роль кнопки электрического провода к торпеде, подложенной под Европу» [14. С. 24].

«В Марокко все дороги ведут в Танжер», - эту марокканскую поговорку привел в «Новом Востоке» М.П. Павлович [12. С. 32]. Как и большинство советских специалистов-международников, он отмечал особое значение Танжера как важного стратегического пункта, очага военных конфликтов между империалистическими державами за гегемонию в западной части Средиземного моря. Танжер вполне мог служить базой для подводных лодок, которые в случае военных действий способны были запереть вход в Средиземное море и перерезать военно-морской путь. Его международный статус был выгоден прежде всего Великобритании, рассчитывавшей не допустить усиления ни одной из конкурирующих держав в регионе. Пусть Франция остается в Марокко, но не трогает Гибралтарского пролива и не подходит к нему слишком близко - такова была английская позиция. Ни Франция, ни немцы, с точки зрения Англии, не должны были господствовать на южном берегу Гибралтарского пролива. Слабой Испании предназначалась в Марокко роль буфера. Франция же стремилась к пересмотру международных договоренностей, к «округлению» своих североафриканских владений. Журнал «Международная летопись» приводил слова чиновника французского МИД Перетти делла-Рока: «Танжер открытые ворота Марокко в Европу. Отказать в Танжере Франции, взявшей на себя заботу о Марокко, - 
значило бы отказать ей в ключе от занимаемого ею дома» [18. С. 75].

Французские власти пытались устранить дипломатию других держав от участия в разрешении данного вопроса, утверждая, что восстание рифов является не международной проблемой, а проблемой внутренней французской. В 1920-х гг. к конкурирующим державам присоединилась Италия, считавшая, что прежние международные договоренности по разделу Марокко не учли ее интересы. Таким образом, «марокканский вопрос» оставался одним из неразрешимых и уязвимых вопросов международной политики. В Советском Союзе считали, что покончить с ним можно, только уничтожив мировую империалистическую систему: «Марокканский вопрос - это порочный круг... Только меч революции способен его разрешить» [19. С. 208].

По единодушному мнению советских специалистов, рифская проблема приобрела международный характер после победы в 1921 г. объединения племен под руководством Абд-аль-Карима над испанской армией под Монт-Арруи. «Война с рифскими кабилами имеет мировое значение: тот, кому подчинен Риф, владеет и лежащей левее Джебалой, а кто владеет Джебалой, тому принадлежит и Гибралтарский пролив», - делали выводы в журнале «Международная летопись» [20. С. 130].

Нарушение регионального статус-кво возродило как опасения, так и надежды конкурирующих европейских держав на изменение ситуации вокруг Марокко. И эти изменения они пытались обратить себе на пользу: развивающийся в Рифе конфликт каждая из держав пыталась использовать, чтобы ослабить противниц. На первом этапе войны, когда рифы сражались с Испанией, оружие и боеприпасы им тайно продавали англичане и французы: «Империализм всех цветов пытался использовать Абд-аль-Карима. В 1922 г. Англия снабжала Риф через Гибралтар оружием и солью, операции велись сугубо «частными» лицами», - писал Д. Лебедев [3. C. 54].

В ходе боевых действий с Испанией обнаружилось, что «туземцы оказались прекрасно вооружены и стояли на значительной высоте современных требований военной техники» - обстоятельство, которое могло явиться лишь в результате содействия, оказанного какой-либо из «нейтральных» сторон [21. С. 238].

Французские газеты обвиняли Берлин в поддержке восставшего Рифа, намекали, что Рим и Лондон также принимали участие в антифранцузской пропаганде. В мае 1925 г. один из руководителей французской Социалистической партии П. Ренодель, выступая во французском парламенте, заявил: «Я был бы очень удивлен, если бы Германия не следила с вниманием и симпатиями за деятельностью Абд-аль-Карима» [5. С. 77].

Французские журналисты писали, что германское правительство находится в постоянной связи с рифами, причем тайный представитель последних находится в Берлине. Даже тот факт, что рифы прибегали к некоторым европейским военным методам, использовался европейской прессой, чтобы скомпрометировать восставших: «Окопы рифиоты строят по-европейски, что, конечно, дает повод пустить версию о переодетом немецком офицере в должности начинжа Абд альКарима» [11. С. 35].

Самого вождя мятежного Рифа газеты европейских держав называли то германским, то большевистским агентом, намекая на получение им денег английских, итальянских, турецких и даже американских. При всей симпатии к личности Абд-аль-Карима советские журналы также сообщали о связях правительства Рифской республики с мировыми империалистическими центрами. Уважаемая газета «Известия» писала: «За последние годы Республика рифов успела тесно связаться с Англией. Она имела в Лондоне полномочного представителяангличанина, обладавшего широкими полномочиями, между прочим, для раздачи концессий в Республике рифов. Этот английский представитель Абд-аль-Карима обращался и к советскому полпредству в Лондоне с предложениями концессий в Республике рифов. Не удивительно, что при такой близости к Англии Республика рифов приобрела от нее оружие» [16].

Открытая официальная позиция Советского Союза по моральной поддержке восставших рифов вызывала в европейских столицах очевидное противодействие на уровне пропаганды. И Мадрид, и Париж были склонны объяснять собственные промахи и поражения в Марокко вмешательством «руки Москвы». Председатель правительства Испании Примо-де-Ривера заявлял, что «рифский бунт был спровоцирован большевистскими агентами» [10. С. 9]. Депутат французского парламента утверждал, что «большевизм стремится проводить националистическую пропаганду среди колониальных народов всего мира, чтобы расширить свое влияние» [5. С. 77].

Доставалось и французским коммунистам, которые боролись за прекращение войны в Марокко: их парижская пресса называла «изменниками родины, подкупленными Москвой». Д. Лебедев упоминает, что в мемуарах Абд-аль-Карима есть эпизод, когда французский корреспондент спрашивает вождя рифов, правда ли они получают «московскую дотацию». Такое предположение было Абд-аль-Каримом со смехом опровергнуто [3. С. 54]. Газета «Известия» прямо и резко подтверждала, что никаких связей, кроме моральной поддержки, между Советским Союзом и Республикой Риф не существовало: «Для французских генералов Советская республика - весьма удобный козел отпущения. Свои неудачи в кампании против рифов они объясняют нелепой сказкой о мнимой помощи СССР Абд-аль-Кариму. Это детская выдумка. При малейшем знакомстве с фактами становится ясно, что СССР не имеет никаких сношений с Республикой рифов» [16]. Следует полагать, что советское руководство весьма трезво оценивало отсутствие идеологического потенциала в политике Абд-аль-Карима и не питало иллюзий на его счет. 
Советский Союз был готов отстаивать интересы марокканского народа дипломатическими средствами. В 1926 г., когда борьба европейских держав вокруг Марокко достигла наивысшего накала, возникла идея созыва новой международной конференции для пересмотра Альхесирасских договоренностей, приглашения рассылались всем державам, представители которых присутствовали на исторической конференции в 1906 г. Правительство СССР в связи с предполагавшейся международной конференцией 10 августа 1926 г. обратилось с нотой к правительствам Англии, Франции, Италии и Швеции, содержащей протест против игнорирования прав советского правительства, которому не было послано приглашение на эту конференцию. СССР требовал себе права присутствия на конференции. «Не для захвата территории марокканских племен явились бы представители Советского Союза на конференцию, не для участия в грабеже этой несчастной колонии, а для вящей защиты этих племен от хищных аппетитов империализма. Царское правительство выговорило себе долю в размере $2 \%$ общей суммы вкладов в "Государственном Банке Марокко”. Советские представители не для торга и переторжек прибыли бы на конференцию, а как защитники угнетенного Марокко против стаи империалистических шакалов» [22. С. 68].

Капитуляция рифских племен под руководством Абд-аль-Карима в 1926 г. под натиском европейской военной мощи была для Москвы событием ожидаемым, но встреченным с большим сожалением. Она расценивалась как «начало нового стремительного наступления мирового империализма на страны Востока». При этом специалисты отмечали, что победа французского империализма в Марокко не принесла Франции желаемых территориальных приращений.
Риф оставался в зоне влияния Испании и под испанским протекторатом. Франция должна была вывести оттуда свои войска. Французская буржуазия была крайне недовольна исходом кампании. «Неужели Франция пожертвовала 15 тысяч солдат и 2 миллиарда франков только в интересах испанского короля?»- с раздражением спрашивали французские буржуазные газеты [5. С. 68]. Таким образом, Марокко продолжало оставаться яблоком раздора для европейских держав и источником военной опасности для континента.

В то же время советская пресса выражала уверенность в будущем освобождении марокканского и других арабских народов от ига колониализма в том, что борьба рифов, являвшаяся частью общей борьбы арабских народов за независимость, была прологом к достижению общей цели: «Блестящие победы Абд-альКарима дают неслыханной силы толчок национальноосвободительному движению всех колониальных народов. Во всем мусульманском мире имя Абд-аль-Карима окружено ореолом и является символом расцветающих надежд на грядущее освобождение от ига империалистов» [2. С. 23]. Бескомпромиссная, прямая поддержка Советским Союзом борьбы марокканцев за свободу, несомненно, воодушевляла восставших. Один из сподвижников Абд-аль-Карима заявил в интервью для французской газеты «Эвр»: «Россия освободилась от угнетателей, и мы идем по ее пути. Через десять лет вся Африка будет независимой» [14. С. 31]. Объективно прогрессивная и гуманная позиция Советского Союза по поддержке правой борьбы марокканцев, несомненно, внесла вклад в становление советско/российско-арабских дружественных отношений на последующих исторических этапах.

1. Яковлев В.И. Борьба за Марокко. Л., 1926.

\section{ЛИТЕРАТУРА}

2. Мирский (Фрунзе) М. Европейские цивилизаторы и Марокко. М. : Изд-во журнала «Военный Вестник», 1925.

3. Лебедев Д. Республика Риф. М. ; Л., 1931.

4. Ковалев А. Диссертация о войне в Марокко // Военно-исторический журнал. 1939. № 4.

5. Тарханов О. Рифская освободительная война // Борьба классов. 1931. № 8-9.

6. VI расширенный пленум ИККИ. Стенографический отчет. 1926.

7. Луцкая Н.С. Борьба французских коммунистов против колониальной войны в Марокко // Вопросы истории. 1951. № 9.

8. Ходоров А.Е. Китай и Марокко. Л. : Плановое хозяйство, 1925.

9. Сталин И.В. О политических задачах университета народов Востока: речь на собрании студентов КУТВ 18 мая 1925 г. // Сталин И.В. Сочинения. М., 1952. Т. 7.

10. Павлович М. Капитуляция Абд-эль-Керима и трагедия Риффа // Новый Восток. 1926. № 13-14.

11. Ланговой. Новая колониальная война в Марокко // Военный вестник. 1925. № 21.

12. Kann R. La situation au Maroc // Le Temps. 23 août 1925.

13. Китайгородский П. За Марокко - Сирия // Военный вестник. 1925. № 29.

14. Thibau J. Disposition des esprits en Tunisie// Le Temps. 16 mai 1925.

15. Ланговой. Боевые действия в Марокко в 1925 г. // Военный вестник. 1926. № 3.

16. Франция и Марокко. Одна из международных болячек // Известия. 1925. № 150 (2483), 4 июля.

17. Данциг Б. Фашистская Германия и Марокко // Мировое хозяйство и мировая политика. 1937. № 12.

18. Танжерский вопрос // Международная летопись. 1924. № 1.

19. Китайгородский П. Марокко как объект колониальной политики // Плановое хозяйство. 1925. № 7.

20. Гедин С. За кулисами войны в Марокко // Международная летопись. 1925. № 12.

21. Мсерианц М. Испания в Марокко // Военная мысль и революция. 1924. № 6.

22. Китайгородский П. Перегруппировка сил в западном секторе Средиземного моря // Большевик. 1927. № 2.

Zherlitsina Natalia A. Institute for African Studies of Russian Academy of Sciences (Moscow, Russia), Peoples' Friendship University of Russia (Moscow, Russia). E-mail: ns_inafr@mail.ru

"DEFENDER OF OPPRESSED MOROCCO": TREATMENT OF THE RIF WAR QUESTION IN THE SOVIET UNION IN THE $1920^{\mathrm{TH}}$. 
Keywords: USSR; Morocco; Rif War; anti-colonial struggle; ideological press.

The article considers the peculiarities of treatment of the Rif War question in the Soviet Union. Struggle of tribes of the mountainous region of Rif in Morocco against the French and Spanish colonialism in 1921-1926 was widely covered by the Soviet press; it was the subject of research in the scientific works and articles of Soviet statesmen. The aim of this research was to identify the reasons of great interest in the USSR to the events in North Africa; to carry out the analysis of ideological postulates on which the Soviet position was based; to define the main questions drawing attention of the Soviet researchers of Morocco of that period; to consider the international reaction and consequences of the position on unconditional support of liberating fight of Moroccans taken by the Soviet Union. This research is based on articles of heads of the countries of that period, Comintern documents, publications in Oriental, ideological and military press of the Soviet Union in $1920^{\text {th }}$, in such magazines as "Novyy Vostok [New East]", "Vostok i kolonii [East and colonies]", "Bor'ba klassov [Class Struggle]", "Voennyy vestnik [Military Herald]", "Voennaya mysl' i revolyutsiya [Military thought and revolution]", "Mezhdunarodnaya letopis' [International chronicle]" and "Bolshevik". Fastidious attention of some Soviet specialists to all the details unfolding in the North African conflict was due to the serious international complications and, not least, the expectations in Moscow on the growth of the revolutionary movement in the Arab East. Supporting the struggle of the Rif tribes for liberation from colonial rule, Soviet authors, guided by ideological dogmata, based on the postulate about the "anti-imperialist" and "national liberation" war. However, this assessment had many weaknesses. Feudal and Patriarchal Morocco did not fit the role of the country in which could happen the proletarian revolution. Due to the ensuing discussions, the question of the nature of the war in the Rif was discussed at the Plenum of the Executive Committee of the Comintern. The heads of the young Soviet Republic also identified their position. Special attention in the USSR was devoted to such aspects of the Rif war, as the lack of a clear religious nature of the movement under the leadership of Abd al-Karim; the possibility of escalation of the war in Morocco in the pan-Arab uprising in North Africa and international consequences of this confrontation. The open position of the Soviet Union for moral support for the rebels reefs caused in European capitals obvious opposition in the level of propaganda. Madrid and Paris were inclined to explain their own failures and defeats in Morocco by the intervention of the "hand of Moscow". Although there are no ties, in addition to moral support, between the Soviet Union and the Republic of the Rif existed, the USSR was ready to defend the interests of the Moroccan people by diplomatic means. Main conclusions: although the analysis of the Soviet position in support of the liberation struggle of Moroccans shows the presence of some contradictions and ideological exaggeration, but objectively progressive and humane position of the Soviet Union undoubtedly contributed to the formation of the Russian-Arab friendly relations.

\section{REFERENCES}

1. Yakovlev, V.I. (1926) Bor'ba za Marokko [The struggle for Morocco]. Leningrad: State Publ.

2. Mirskiy, M. (1925) Evropeyskie tsivilizatory i Marokko [European civilizing and Morocco]. Moscow: Voennyy Vestnik.

3. Lebedev, D. (1931) Respublika Rif [Republic of the Rif]. Moscow; Leningrad: State Social and Economic Publ.

4. Kovalev, A. (1939) Dissertatsiya o voyne v Marokko [Dissertation on the war in Morocco]. Voenno-istoricheskiy zhurnal. 4.

5. Tarkhanov, O. (1931) Riffskaya osvoboditel'naya voyna [The Rif Liberation War]. Bor'ba klassov. 8-9.

6. The Sixth Enlarged Plenum of The Executive Committee of the Communist International. (1926).

7. Lutskaya, N.S. (1951) Bor'ba frantsuzskikh kommunistov protiv kolonial'noy voyny v Marokko [French Communists fighting against the colonial war in Morocco]. Voprosy istorii. 9.

8. Khodorov, A.E. (1925) Kitay i Marokko [China and Morocco]. Leningrad: Planovoe khozyaystvo.

9. Stalin, I.V. (1952) Sochineniya [Works]. Vol. 7. Moscow.

10. Pavlovich, M. (1926) Kapitulyatsiya Abd-el'-Kerima i tragediya Riffa [The surrender of Abd el-Kerim and Rif tragedy]. Novyy Vostok. 13-14.

11. Langovoy. (1925) Novaya kolonial'naya voyna v Marokko [The new colonial war in Morocco]. Voennyy vestnik. 21.

12. Kann, R. (1925) La situation au Maroc [The situation in Morocco]. Le Temps. 23rd August.

13. Kitaygorodskiy, P. (1925) Za Marokko - Siriya [Syria after Morocco]. Voennyy vestnik. 29

14. Thibau, J. (1925) Disposition des esprits en Tunisie [Disposition of the spirits in Tunisia]. Le Temps. 16th May.

15. Langovoy. (1926) Boevye deystviya v Marokko v $1925 \mathrm{~g}$. [Fighting in Morocco in 1925]. Voennyy vestnik. 3.

16. Anon. (1925) Frantsiya i Marokko. Odna iz mezhdunarodnykh bolyachek [France and Morocco. One of the international sores]. Izvestiya. 150(2483). 4th July.

17. Dantsig, B. (1937) Fashistskaya Germaniya i Marokko [Nazi Germany and Morocco]. Mirovoe khozyaystvo i mirovaya politika. 12.

18. Anon. (1924) Tanzherskiy vopros [The issue of Tangier]. Mezhdunarodnaya letopis'. 1.

19. Kitaygorodskiy, P. (1925) Marokko kak ob"ekt kolonial'noy politiki [Morocco as an object of colonial policy]. Planovoe khozyaystvo. 7.

20. Gedin, S. (1925) Za kulisami voyny v Marokko [Behind the scenes of the war in Morocco]. Mezhdunarodnaya letopis'. 12.

21. Mseriants, M. (1924) Ispaniya v Marokko [Spain in Morocco]. Voennaya mysl' i revolyutsiya. 6.

22. Kitaygorodskiy, P. (1927) Peregruppirovka sil v zapadnom sektore Sredizemnogo morya [Regrouping of forces in the western sector of the Mediterranean Sea]. Bol'shevik. 2. 